\title{
Det skjulte spil
}

\section{af Bjørn Svensson}

Da en grænserevision tegnede sig efter Tysklands nederlag i den første verdenskrig, søgte ministeriet Zahle at sikre den kommende landegrænse ved at få Nordslesvigs genforening med Danmark gennemført $i$ et samarbejde med den tyske regering, men disse bestræbelser, der tilsigtede at forhindre eller formindske Fredskonferencens indblandingsmuligheder, måtte skjules både over for den danske opposition og de allierede sejrherrer.

Bjørn Svensson kaster nyt lys over »det skjulte spil« og dermed over et kapitel $\mathrm{i}$ grænsestriden, der trak megen bitterhed efter sig.

Det er hævet over al tvivl, at Troels Finks tre bind om tiden "Da Sønderjylland blev delt 1918-1920« vil blive stående som standardværket om grænsedragningen i 1920 og dens historie. Det kan der gives mange og gode grunde for. Men også et standardværk kan behøve afpudsning, og Troels Fink har med sin artikel i Sønderjyske Årbøger 1980 om Flensborgspørgsmålet selv erkendt, at der kan være brug for uddybning og udfyldning.

Med et andet udgangspunkt end Troels Finks har jeg i artikler i Sønderjysk Månedsskrift søgt at bidrage til en belysning af grænsespørgsmålet, der i højere grad sætter projektørerne på fra oppositionssiden, ligesom det er sket i min bog "Tyskerkursen«. Det er i forlængelse heraf, man skal se min skildring i "Det skjulte spil» af den balancegang mellem hensynet til den tyske taber og de allierede sejrherrer, som regeringen og dens støtter forsøgte sig med $\mathrm{i}$ oktober/november 1918, idet jeg særlig fremhæver de forhold, som de implicerede ønskede at holde skjult.

\section{Planen om et dansk-tysk fait accompli}

Det var det radikale ministerium Zahle med Th. Stauning som socialdemokratisk støtteminister, der fik arbejdet med at løse grænsespørgsmålet.

Troels Fink har kridtet banen korrekt op med sin konstatering af, at udenrigsminister Erik Scavenius den 23. oktober 1918, da fællesmødet mellem Rigsdagens to ting blev holdt, var kommet til klarhed over, at det dansk-tyske grænsespørgsmål før eller siden ville komme for Fredskonferencen, men dog fandt han det lige vigtigt for Danmark, at løsningen mødte forståelse fra tysk side. ${ }^{1}$ Fink noterer, at det var »kun som følge af situationens pres, at Scavenius 
opgav tanken om en dansk-tysk forhåndsforståelse «. ${ }^{2}$ Men endnu under en drøftelse mellem ministre og partiformænd den 17. oktober hævdede Scavenius det standpunkt, at sagen måtte lægges fast før Fredskonferencen. ${ }^{3}$

Erik Scavenius har i $\sin$ bog $» D a n s k$ udenrigspolitik under den første verdenskrig « lagt et tæt røgslør over sin holdning til grænsespørgsmålets løsning. Da den danske gesandt i Berlin, grev C.Moltke, i november 1914 foreslog at rette en henvendelse til den tyske regering for at fremkalde en ændret tysk holdning i det nationalpolitiske mellemværende, afslog Scavenius at gøre det "nu«. Og så fortsatte han i bogen med at understrege, at så meget mindre kunne han tænke sig muligheden af at indlede direkte dansk-tyske statsforhandlinger efter det tyske nederlag i 1918, thi dette at rejse spørgsmålet over for den tyske regering "måtte være en opgave for de danske slesvigeres repræsentant i Berlin, rigsdagsmand H.P.Hanssen, og jeg billigede derfor, at professor Aage Friis rejste til Berlin for at orientere ham om den danske regerings politik «. ${ }^{4}$

Denne fremstilling er ikke blot værdiløs. Den er direkte vildledende.

Der havde nemlig været flere faser i udenrigsministerens vurderinger. Den 10. februar 1917 regnede Scavenius med to mulige udfald af krigen. Hvis Tyskland sejrede, kunne det $i$ det højeste onskes, at Nordslesvig fik en art Luxembourg-stilling med selvstyre og fritagelse for værnepligt. Men det bedste ville være en udsoning mellem Tyskland og England, så Tyskland tilbagegav Nordslesvig imod, at England betalte med kolonier ude i verden. ${ }^{5}$ - En dansk ønskedrøm!

Et vendepunkt i holdningen kom under en sammenkomst mellem de ledende ministre hos regeringschefen, C.Th. Zahle, den 23. september 1918. Da tegnede der sig for regeringen en tredie mulighed, som Scavenius i 1917 ikke havde værdiget en overvejelse, nemlig, at Tyskland kunne lide nederlag, foreløbig dog kun som en forventet tilbagegang udstrakt over lang tid, men tilstrækkelig tydelig til, at forsvarsministeren, P. Munch kunne pege på et nyt perspektiv:

"I samtalens løb gjorde jeg en bemærkning til Scavenius om, at det var jo bedst, om han kunne forekomme de chauvinistiske bevægelser ved at enes med tyskerne om Nordslesvig i god tid. Han sagde, at det kunne jo kompromittere over for Ententen. Jeg svarede, at jeg ikke var sikker på, at det hele ikke havde udviklet sig således, at det nu kunne ske uden at kompromittere..... ${ }^{6}$

Munchs tanke blev til regeringens politik. Zahles holdning refereres af Aage Friis efter en samtale mellem dem den 9. oktober 1918 ifølge Fink således: "Vi drøftede, hvorvidt en ordning skulle tilvejebringes i forståelse med Tyskland, hvad vi begge anså for det heldigste, eller om det var muligt, gennem henvendelse til Ententemagterne og rejsning af kravet ved den almindelige fredsforhandling. ${ }^{7}$ 


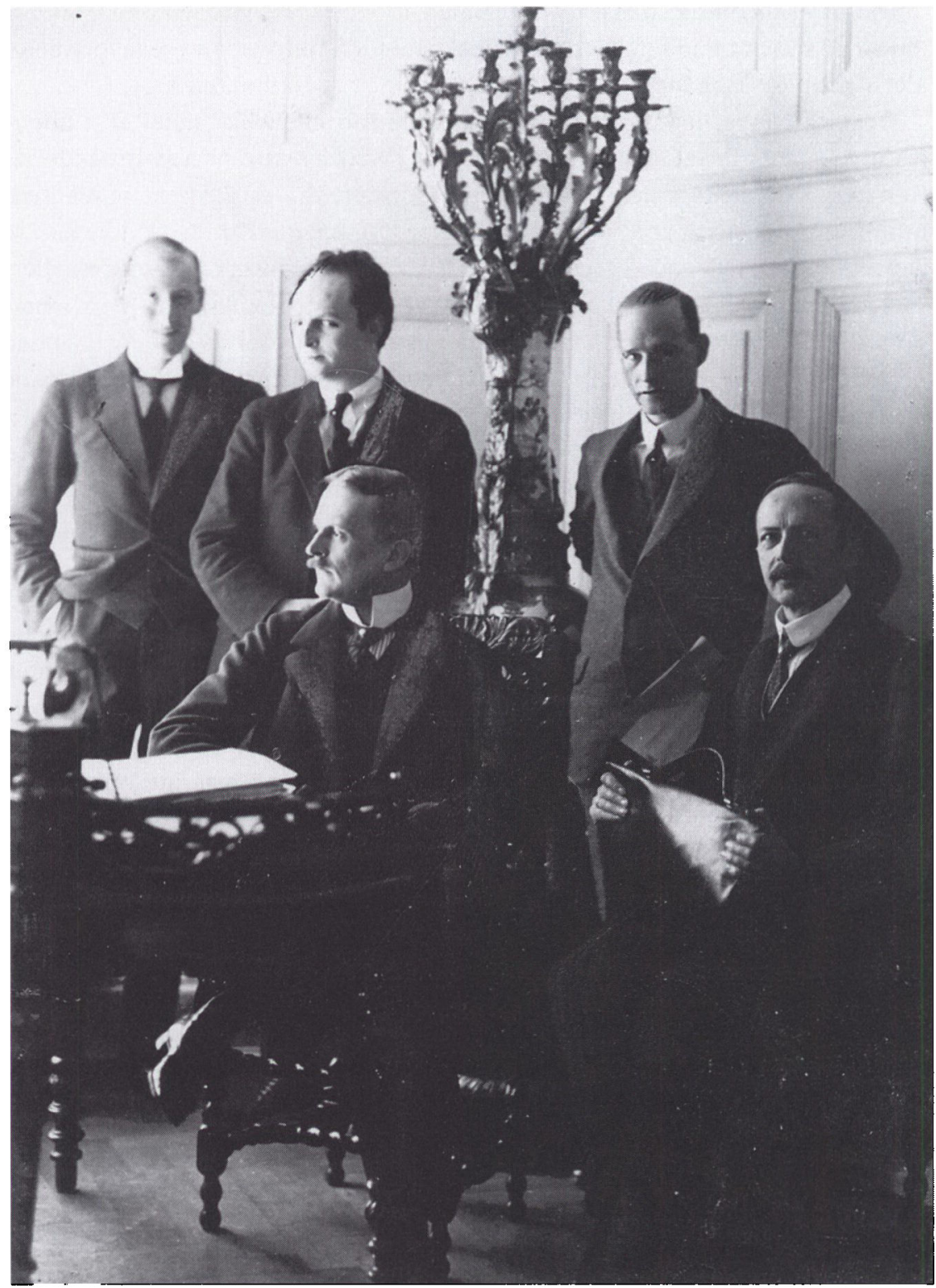

Grev Ulrich Brockdorff-Rantzau (1869-1928) var tysk gesandt i Kobenhavn 1912-18. Som sådan var han en central person $i$ udet skjulte spilk om Sonderjyllands fremtid. I 1919 blev han udenrigsminister $i$ ministeriet Scheidemann, hvor han nagtede at underskrive Versailles-traktaten. Derfor trädte han tilbage i juni 1919 .

$H e r$ ses greven siddende $i$ midten sammen med den tyske republiks udenrigsministerium. Foto $1919 i$ Det kongelige Bibliotek. 
Citatet er imidlertid forkert. I originalen står der ikke »muligt«, men »umuligt«, og i stedet for »i forståelse med Tyskland« skal ordlyden være »i forståelse alene med Tyskland ${ }^{8}$

Det er på baggrund af originalens skarpere formulering, man skal se udenrigsministerens forhandling med den tyske gesandt, grev Ulrich BrockdorffRantzau, samme dag, den 9. oktober 1918. Scavenius ønskede at præsentere de allierede for et fait accompli. Da Rantzau spurgte, om Danmark ikke kunne henvende sig til den tyske regering med ønsket om at få løst grænsespørgsmålet, svarede Scavenius, at det kunne skade over for Ententemagterne, der kunne opfatte det som en separataftale, som indeholdt løn for holdningen under krigen. Scavenius, der delte den opfattelse, at det var bedst både for Danmark og Tyskland at få den sag ordnet før en almindelig fredskonference, foreslog $\mathrm{i}$ stedet, at den tyske regering »af egen fri drift « skulle tilbyde den nordslesvigske befolkning en afstemning om overgang til Danmark. "Forhandlingen med Danmark kunne da komme bagefter og indskrænkes til en forhandling om udførelsen af overgangen.«

Rantzau, der skulle rejse til Berlin dagen efter, erklærede at ville virke af al magt for gennemførelsen af Scavenius' plan. Men forinden havde han endnu en samtale med den danske udenrigsminister, efter at denne havde konfereret med Zahle, der ville have Friis sendt til Berlin for at sikre sig, at H.P. Hanssen ikke krydsede regeringens politik. "Det var dog endt med, at Scavenius anså det for bedre, at Hanssen blev underrettet fra den tyske regering om, at der var villighed til imødekommenhed, men at han måtte holde sig tilbage.» Rantzau fik omgående den nødvendige orientering.

Denne fremstilling, som vi skylder P.Munch', viser jo, at Scavenius i hvert fald på dette tidspunkt ikke lagde det hen til de danske slesvigere at rejse grænsespørgsmålet, og at Friis heller ikke skulle rejse til Berlin for at opmuntre H.P.Hanssen til at gøre det, men at Scavenius tværtimod ville søge at få den tyske regering til at afholde Hanssen fra det, som Scavenius i sine erindringer fremstiller som dennes opgave.

Grev Rantzau fremlagde den scavenianske plan for den tyske regering i et memorandum, som han færdiggjorde i Berlin den 17. oktober. Men samme dag blev Scavenius bremset noget i mødet med de danske partiledere. Scavenius gav et referat af mødet til den tyske chargé d'affaires i København, Wittgenstein, der på dette grundlag indberettede til Berlin, at afgørelsen efter dansk opfattelse først kunne komme paa Fredskonferencen, men at et tysk tilsagn til de dansktalende befolkningsdele dog kunne lette forhandlingerne. ${ }^{10}$

Socialdemokraten Th. Stauning havde på mødet den 17. oktober taget skarpt afstand fra at føre grænsespørgsmålet frem på Fredskonferencen. Han stolede på, at hans tyske partifæller ville tage initiativ til at ordne sagen forinden. 
I krigens andet år havde Stauning med den tyske partiledelse haft en drøftelse, som han - for umistænksomt - i Socialdemokraten den 31. oktober 1915 udlagde som en bekræftelse på, at det tyske socialdemokrati fremdeles over for Nordslesvig hævdede selvbestemmelsesretten med henblik på samhørighed med en nation.

Først to år efter dementerede det tyske socialdemokrati Staunings udlægning. I et memorandum af 12 . juni 1917 frakendte SPD nordslesvigerne folkenes selvbestemmelsesret med den begrundelse, at det her ikke drejede sig om et folkeslag, der havde haft politisk uafhængighed i et selvstændigt statsliv. Nordslesvig kunne derfor kun tilkomme autonomi inden for det tyske rige.

Efter denne skuffelse måtte de danske socialdemokrater tilslutte sig et hollandsk-skandinavisk fredsforslag af 10. oktober 1917, som for Nordslesvigs vedkommende anbefalede en fredelig overenskomst mellem de to lande efter en forudgående folkeafstemning, - en uforpligtende formulering, der bærer præg af Staunings penneføring. Det var også efter dansk ønske, at det blev betonet, at spørgsmålet ikke havde sammenhæng med krigen og dens afslutning.

Endog dette sagtmodige fredsforslag blev afvist af de tyske partifæller. Først i august-september 1918, da nederlaget truede, kunne de -og selv da kun med visse forbehold- bekvemme sig til at acceptere de hollandsk-skandinaviske fredstanker og blot som et forhandlingsgrundlag. "

Alligevel optrådte Stauning som optimist på mødet den 17. oktober 1918. Men han gjorde også sit til at fremkalde det ønskede resultat. Næste dag, den 18. oktober, rettede han skriftligt en henvendelse til de to partifæller i den tyske regering, Gustav Bauer og Philipp Scheidemann. Af diskretionshensyn var den stilet til den ledende tyske socialdemokrat, senere rigspræsident Friedrich Ebert. Formelt var der kun tale om et brev fra en dansk socialdemokrat til en tysk partifælle, men i realiteten var det en henvendelse fra et medlem af den danske regering til den tyske regering.

Minister Th. Stauning gentager i brevet Scavenius-forslaget om, at Tyskland "på eget initiativ« i en erklæring skulle tilbyde den nordslesvigske befolkning selvbestemmelsesret og samtidig bebude, at den tyske regering ville søge kontakt med den danske regering vedrørende de former, under hvilke spørgsmålet kunne løses, altså med hensyn til grænse, afstemning osv. ${ }^{12}$

Stauning forklarer udførligt de mange fordele ved denne plan for begge lande og for begge de socialdemokratiske partier, idet man berøver Ententen det agitationsstof, sagen ellers frembyder. Stauning forsikrer, at hans parti deler disse synspunkter, og tilføjer med streg under, at den samme opfattelse også råder andetsteds, hvilket må sigte til den danske regering. I det hele taget kunne han jo ikke gå ind $\mathrm{i}$ denne aktion uden sikkerhed for, at udenrigsminister 
Scavenius ville tage vel imod en sådan tysk henvendelse, selv efter det bremsende møde med partilederne dagen før. Man må gå ud fra, at aktionen er foretaget i mere eller mindre direkte forståelse med Scavenius.

Men alt skulle holdes hemmeligt. Stauning fremhæver, at den danske regering af hensyn til Ententen er afskåret fra at henvende sig officielt til Tyskland, og han sætter tykke streger under nødvendigheden af at hemmeligholde brevet med hensyn til såvel indhold som afsender.

Vi kender ikke den behandling, Staunings brev fik. Men rygterne om en dansk henvendelse til Berlin tog fart et par dage efter. At de blev dementeret både fra dansk og tysk side, siger intet. Hvis det drejede sig om Staunings brev, var det jo forud hjemfaldet til dementier. Men kunne der vare tale om andet?

I danske regeringskredse gættede man først på Wittgenstein, men da han nægtede at have været for åbenmundet om den orientering, han havde fået af Scavenius, afviste regeringen det hele som rygter, der savnede ethvert grundlag. Selv om altså Scavenius tilsyneladende havde givet Wittgenstein et grundlag. Forsvarsminister P. Munch og Aage Friis tænkte også på H.P.Hanssen som en mulighed, og Harald Jørgensen har senere gættet på grev Rantzau som kilden ${ }^{13}$, men ingen af dem passer ind i billedet. Det gør derimod Stauning.

H.P.Hanssen noterer i sin dagbog den 20. oktober 1918: „Da jeg i dag ville forlade Rigsdagen, blev jeg standset af dr. Friedegg, som fortalte, at han havde en vigtig nyhed til mig. Der var indløbet en dansk note til Berlin, som rejste det nordslesvigske spørgsmål. Han kom lige fra Udenrigsministeriet, hvor man havde meddelt ham det. Noten var blevet overrakt af den danske chargé d'affaires, da gesandten var i København. Dr. Friedegg havde straks ladet meddelelsen gå videre til sit blad i Wien.«

Oplysningerne er for konkrete til, at det hele kan være grebet ud af luften. Man ved, at der ikke er afleveret en officiel note. Der kan derfor kun være tale om en uofficiel henvendelse. Vi ved endvidere:

1) at Friedegg lige er kommet fra Udenrigsministeriet, 2) at han der er blevet orienteret om en dansk henvendelse, 3) at den hævdes overrakt af en mand fra det danske gesandtskab, der er angivet som chargé d'affaires, og at hans optræden er begrundet med, at gesandten selv er i København, hvilket i hvert fald er korrekt.

Derudover har intet kunnet kontrolleres. Henrik Kauffmann gjorde tjeneste i det danske gesandtskab i Berlin på den tid, men desværre indeholder hans privatarkiv i Rigsarkivet udelukkende sager fra hans tid i U.S.A.

Det kan tænkes, at det danske udenrigsministerium har hjulpet Stauning med at give hans brev en hurtig og sikker fremsendelse under de urolige forhold. Og formodningen om en Stauning-sammenhæng styrkes af en oplys- 
ning i Hamburger Fremdenblatt den 20. oktober om, at den danske henvendelse indeholdt onske om at få gennemført et traktatpunkt fra $1860^{\prime} e r n e$, der ikke havde fundet afgørelse (sigtende til Pragfredens $\S 5$ ). Det var just, hvad Stauning havde peget på i sit brev i håb om, at det kunne lette de tyske socialdemokrater opgaven at henvise til, at det var Bismarck, der havde fået $\S 5$ annulleret. Scavenius og Friis-kredsen var derimod bange for at genoplive $\S 5$, fordi det ville kunne styrke kravet om at få Flensborg, som i 1860'erne havde dansk flertal, med til Danmark.

Der kunne imidlertid ikke komme noget ud af den plan, Erik Scavenius havde fremlagt, hverken via grev Rantzau eller gennem Staunings socialdemokratiske regeringskontakter i Berlin. København havde forset sig paa sine egne problemer i den grad, at man overså, at Berlins vanskeligheder ikke var mindre, men tværtimod blev forøget af de protester, der kunne ventes fra modstanderne af rigets amputation, her især fra Prøjsen og Slesvig-Holsten. Skulle man gå den vej, ønskede Berlin, at udspillet kom fra den danske regering.

\section{Aage Friis forhandler i Berlin for Scavenius}

Den 8. november 1918 havde situationen udviklet sig sådan, at professor Aage Friis besluttede at rejse til Berlin. Han har i »Tilskueren« maj 1921 skrevet en beretning om sin rejse, en redegørelse, der angiver at være »uden forbehold af nogen art« om det virkelige sagsforhold i sammenhæng. Men der var ikke desto mindre væsentlige forbehold; i et notat i sine papirer 1930 har Friis erkendt, at adskilligt i de oprindelige optegnelser måtte udgå af aktuelle hensyn, fordi kampen om grænseafgørelsen endnu rasede i 1921.

Endvidere har Friis i Tilskueren oplyst, at rejsen blev besluttet for at efterkomme et gentagne gange fra H.P.Hanssens side udtalt ønske om, at han skulle komme til Berlin. Dette er blankt urigtigt. Den 17. oktober 1918 havde Hanssen endda gennem kaptajn Ramm fra Røde Kors afvist et tilbud fra Friis om at komme til den tyske hovedstad. Friis gentog derefter sit forslag i breve til Hanssen den 23. og 31. oktober, men uden at denne reflekterede. Han pegede i stedet på de opgaver, Friis burde løse i København. Aage Friis har altså fundet det hensigtsmæssigt at skjule den virkelige begrundelse for rejsen. Hvorfor?

Forklaringen skal nok søges i, at Aage Friis var blevet en ivrig makker for udenrigsminister Erik Scavenius i det slesvigske spil. De havde ellers ligget på krigsfod efter et voldsomt opgør i 1910, da Scavenius fejlagtigt havde troet, at Friis havde modarbejdet hans ønske om at få gesandtposten i Berlin. Efter 


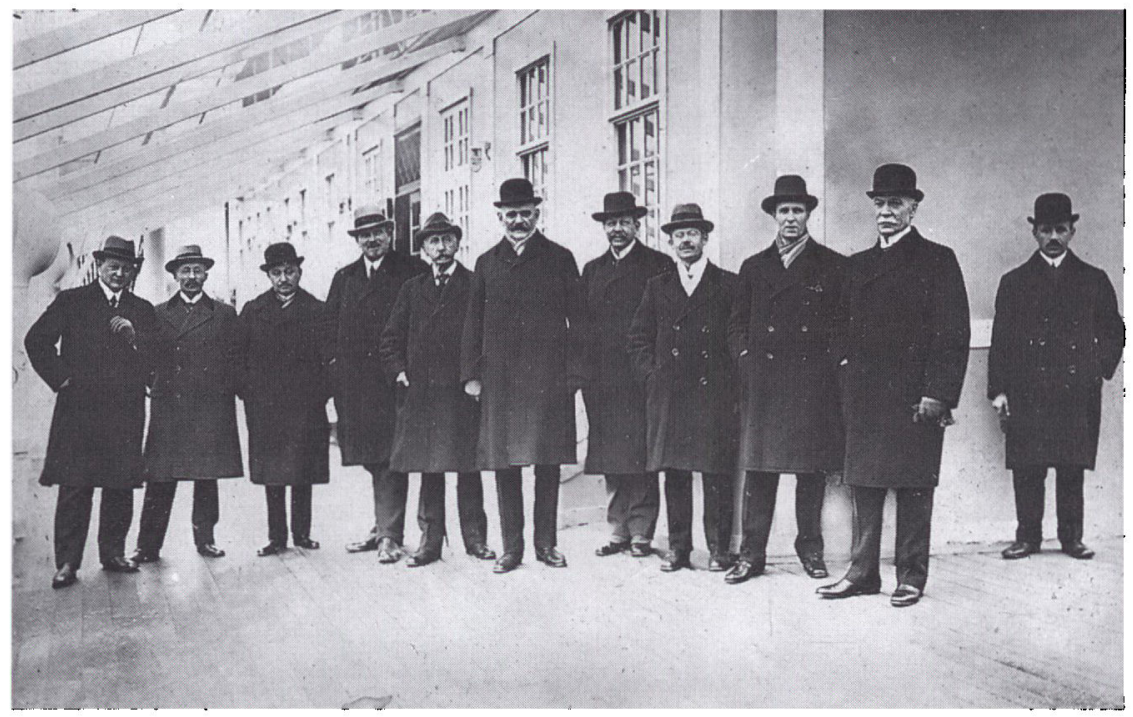

I marts 1919 blev der sendt en kongerigsk-slesvigsk delegation til fredskonferencen i Paris. På fotografiet af delegationen ser man flere af hovedpersonerne fra wdet skjulte spilw. Fra venstre Andreas Grau, Nis Nissen, Emil Glückstadt, H.D. Kloppenborg-Skrumsager, H. P. Hanssen, Niels Neergaard. Alex. Foss. C. V.Bramsnas, P. Munch og H.N. Andersen. Foto i Dansk Centralbibliotek for Sydslesvig.

at de havde trakteret hinanden med uforskammetheder, sås de ikke før den 13. oktober 1918. Det var den såkaldte Oktoberadresse, der bragte dem sammen.

Da Aage Friis sent lørdag aften den 12. oktober fik meddelelse om det tyske svar til præsident Wilson, der varslede snarlige fredsforhandlinger, spekulerede han en del på "vigtigheden af, at vi hurtigt kom til en separat forståelse med Tyskland. Håbet stod jo til at kunne komme en fredskonference i forkøbet. Derfor var det af betydning at stoppe Ejdermændene, og dette skete bedst ved et fornuftigt opråb, der stillede dem over for et fait accomplik.

Dette opråb konciperede Friis næste morgen kl. 4-6, han læste det for H.V. Clausen kl. 8, mødte kl. 9.30 op hos statsminister Zahle, der sluttede sig til forslaget, og det samme gjorde Erik Scavenius, da han indfandt sig. Scavenius foreslog en enkelt andring til sikring af et tysk mindretal (uden tilsvarende ord om et efterladt dansk mindretal), og han ønskede derefter opråbet frem hurtigst muligt, dels for at tage brodden af Ejderagitationen og bremse dens bestræbelser på at sætte Ententen $\mathrm{i}$ bevægelse, dels for at give baggrund for den henvendelse, han agtede at rette til grev Rantzau, når denne vendte tilbage fra Berlin.

Samme dag havde Friis indbudt de tre planlagte medunderskrivere af oprå- 
bet (Oktoberadressen) til at drøfte sagen. Det var det såkaldte "Trekløver«, H.V.Clausen, H.L.Møller og M.Mackeprang, hvoraf den sidste havde medbragt et udkast, som dog ikke kom op af lommen, da nu Friis viste sig med regeringens tilslutning i ryggen. Når adressens forfatter, Aage Friis, ikke selv trådte frem som underskriver, var det sikkert for at afværge indtryk af, at udenrigsministeren gennem ham stod bag adressen. ${ }^{14}$ I stedet underskrev Harald Høffding.

Oktoberadressen var et besynderligt opråb, der prisgav neutraliteten og var en klar provokation over for Ententen, skønt det var dens sejr, der havde givet de danske håb om en genforening, som ellers måtte anses for udelukket. Medens de allierede endnu lod våbnene tale for at få kejseren fjernet, den prøjsiske militarisme knust og den tyske forfatning demokratiseret, henvendte opråbet sig til det endnu eksisterende kejserlige Tyskland og ønskede det en hæderfuld fremtid og lykke, knyttet til en forsikring om den danske vilje til at bygge bro mellem de tidligere fjender, hvilket $i$ den givne situation alene var et tilbud til de tyske tabere. Hvorefter man indtog den ærbødige position: "Vi danske mænd og kvinder vender os til det tyske folk med indtrængende henstilling om højhjertet og klogt at lade den folkelige retfærdighed ske fyldest også over for vort folk! ' $^{15}$

Det var dette program, denne tyskerkurs, der i efteråret 1918 knyttede de to tidligere fjender, Erik Scavenius og Aage Friis, sammen $i$ fælles virke. Samarbejdet blev tæt. Alle ændringer $\mathrm{i}$ adressen blev til godkendelse forelagt udenrigsministeren, der havde langt mere at gøre med den, end han ville være ved. ${ }^{16}$ Ministeren kunne kalde professoren til samtale med den tyske gesandt, og når Friis formanede H.P. Hanssen med oplysning om, at han efter "Trekløverets « mening burde skrive til syv formænd for nationale foreninger for at standse deres »forrykte agitation « $i$ uønsket retning, så var Scavenius hemmelig bagmand. Derimod skjulte Aage Friis ikke, at det var Scavenius, der havde bedt ham forklare H.P.Hanssen betydningen af de nordslesvigske ønskers karakter:

"Jeg er bedt om at sige dig med alt eftertryk, at du må sørge for, at der ikke på dette punkt kommer kludder i og fra Nordslesvig. Instruer dine folk i Nordslesvig om absolut at modsætte sig al tale om en sydligere grænse, og skriv til rektor Hansen derom i så kategoriske udtryk som mulig. Det eneste, der kan bringe Ententen til at fravige grundprincippet, vil være den opfattelse, at nordslesvigerne selv vil noget andet. Derfor pas på dette punkt; det er i virkeligheden den eneste fare for en sund og forstandig udvikling af spørgsmålet. « ${ }^{17}$

Det er naturligvis også Erik Scavenius, der afgør, om Friis skal tage til Berlin for yderligere at manuducere H.P.Hanssen $i$, hvad nordslesvigerne 
skulle mene. Scavenius foretrak længe at beholde Friis i København, men han sagde ja, da Friis meldte sig med rejseønsket den 8 . november. Den dag havde Friis nemlig modtaget et alarmerende brev fra H.P.Hanssen, skrevet den 6 . Der var to ting i brevet, der må have virket opskræmmende paa Aage Friis og skabt bekymring hos Scavenius. Dels åbenbarer H.P. Hanssen, at Flensborg alligevel kan blive et problem. Dels forlanger han nu et dansk initiativ:

"Du må absolut ikke vente, at regeringen [i Berlin] vil give os bestemte tilsagn. Hvad skulle bevæge den dertil? Den har efter tysk synspunkt strakt sig overordentlig vidt med dr. Davids erklæring til mig, som jeg omtalte i mit sidste brev. Den er rede til at lade operationen foretage. Men aktionen må foretages af dem, der skal udføre operationen. Det er Danmark, der som krævende og modtagende her må tage affære. Det er dog selvindlysende. Men i Danmark er man endnu altfor passivt afventende. ${ }^{18}$

H.P. Hanssens brev tvang Friis til Berlin. Da han nåede frem den 12. november kort før midnat, var situationen imidlertid totalt forandret. Det kejserlige Tyskland, som Aage Friis havde tilønsket en hæderfuld fremtid, eksisterede ikke mere. Republikken var udråbt den 9. november, kejseren var flygtet, socialdemokraten Friedrich Ebert var blevet rigskansler, seks folkekommissærer havde overtaget den øverste regeringsmagt den 10 . november, og våbenstilstanden var trådt $\mathrm{i}$ kraft den 11 . november.

H.P.Hanssen var straks i fuld gang med at udnytte sine gode socialistiske kontakter for at tilvejebringe den bindende erklæring fra den nye regering om viljen til at gennemføre folkenes selvbestemmelsesret i Sønderjylland, som han i brevet af 6 . november ikke havde regnet med at kunne få fra den gamle regering. I første omgang havde de nye folkekommissærer dog så travlt med større problemer, at diskussionen om den dansk-tyske grænse måtte udskydes.

Men Troels Fink undervurderer H.P.Hanssens indsats, når han skriver: "Hvad ikke var lykkedes for H.P.Hanssen, det lykkedes nu for Aage Friis. Den 13. november fik han først kontakt med understatssekretær dr. David...; sammen gik Aage Friis og dr. David derpå til udenrigsminister dr. Solf. Han var villig til at komme med en erklæring, hvis man blot kunne finde en form. ${ }^{19}$

Disse kontakter fik Aage Friis ikke den 13., men først den 14. november. Hans forsøg den 13. havde været forgæves. Resultaterne denne dag blev faktisk opnået af H.P. Hanssen, idet han fik samtaler med ikke mindre end tre folkekommissærer: Haase (under hvem dr. Solf fungerede som en næppe tålt udenrigsminister), Scheidemann og Landsberg. Alle tre var positive, og Haase lovede at skrive erklæringen og at fremskaffe de andre folkekommissærers godkendelse af den. ${ }^{20}$

Den 14. november kl. 7 kom Friis til H.P. Hanssen, som udtrykte sin glæde over, at han nu ville få den ønskede erklæring. Han aftalte dog med Friis, at 
denne skulle se at få en samtale med Haase, wfor at jeg under alle omstændigheder kunne få den erklæring, der var stillet mig i udsigt, inden aften, da jeg ikke kunne opsætte min rejse længere, hvis jeg skulle nå til Folkehjem i rette tid «.

I denne forbindelse fik Friis af H.P.Hanssen et nummer af Hejmdal med det opråb, Hanssen den 1. november havde sendt til underskrift i Nordslesvig, og som under henvisning til, at Tyskland loyalt ville opfylde præsident Wilsons program, indtrængende opfordrede Rigsledelsen til ved den forestående fredsslutning at løse det nordslesvigske spørgsmål på grundlag af folkenes selvbestemmelsesret.

Når opråbet er offentliggjort, har den tyske regering atter ordet, noterede H.P. Hanssen i sin dagbog den 1. november. Nu var offentliggørelsen sket og det med underskrifter, som repræsenterede 287 danske foreninger i Sønderjylland, herunder iøvrigt også en række foreninger i Flensborg, som H.P.Hanssen ikke havde tiltænkt retten til at stemme.

Den tyske regeringserklæring, som Friis modtog, gav et direkte svar på dette opråb og konkluderede: "Den tyske regering står derefter på det standpunkt, at også det nordslesvigske spørgsmål i henhold til præsident Wilsons fredsprogram bør løses på grundlag af den pågældende befolknings selvbestemmelsesret.«

Skal man dele fortjenesten, må man nok erkende, at H.P.Hanssen havde gjort det grundlæggende arbejde, og at Aage Friis i denne sammenhæng hovedsagelig havde fungeret som postbud, omend med æren for, at Hanssen fik sin erklæring med til Folkehjem. H.P.Hanssen må have vurderet det på lignende måde, for i sin artikel i bind VIII af »Det danske folks historie«, side 446, omtaler han alene sin egen rolle. Friis nævner han ikke.

Aage Friis har i Tilskueren forklaret, hvorfor man ikke på Folkehjem kunne nøjes med det tyske underhåndstilsagn til H.P. Hanssen. Men han udelod fra originalen denne afslørende begrundelse fra H.P. Hanssen: "Det ville vanskeliggøre at fastslå den nationale grænse, idet der var en hidsig agitation i gang fra Danevirkemændenes side, særlig i Flensborg.« - Det var med andre ord behovet for et taktisk modtræk over for Flensborg, der skabte hastværket med at få den officielle regeringserklæring fra udenrigsminister Solf med til Folkehjemsmødet.

Aage Friis var mistænkt for ud over postbudrollen at have andre opgaver at varetage under sine forhandlinger. For eksempel oplyste H.D. KloppenborgSkrumsager senere, at han havde det indtryk, at Hanssen og Friis tumlede med noget, som Nis Nissen og han selv, skønt begge landdagsmænd i Berlin, skulle holdes uvidende om. Nissen kom en dag og var fortrydelig over, at Hanssen havde blæst ham ud af sit værelse, da han havde en forhandling 


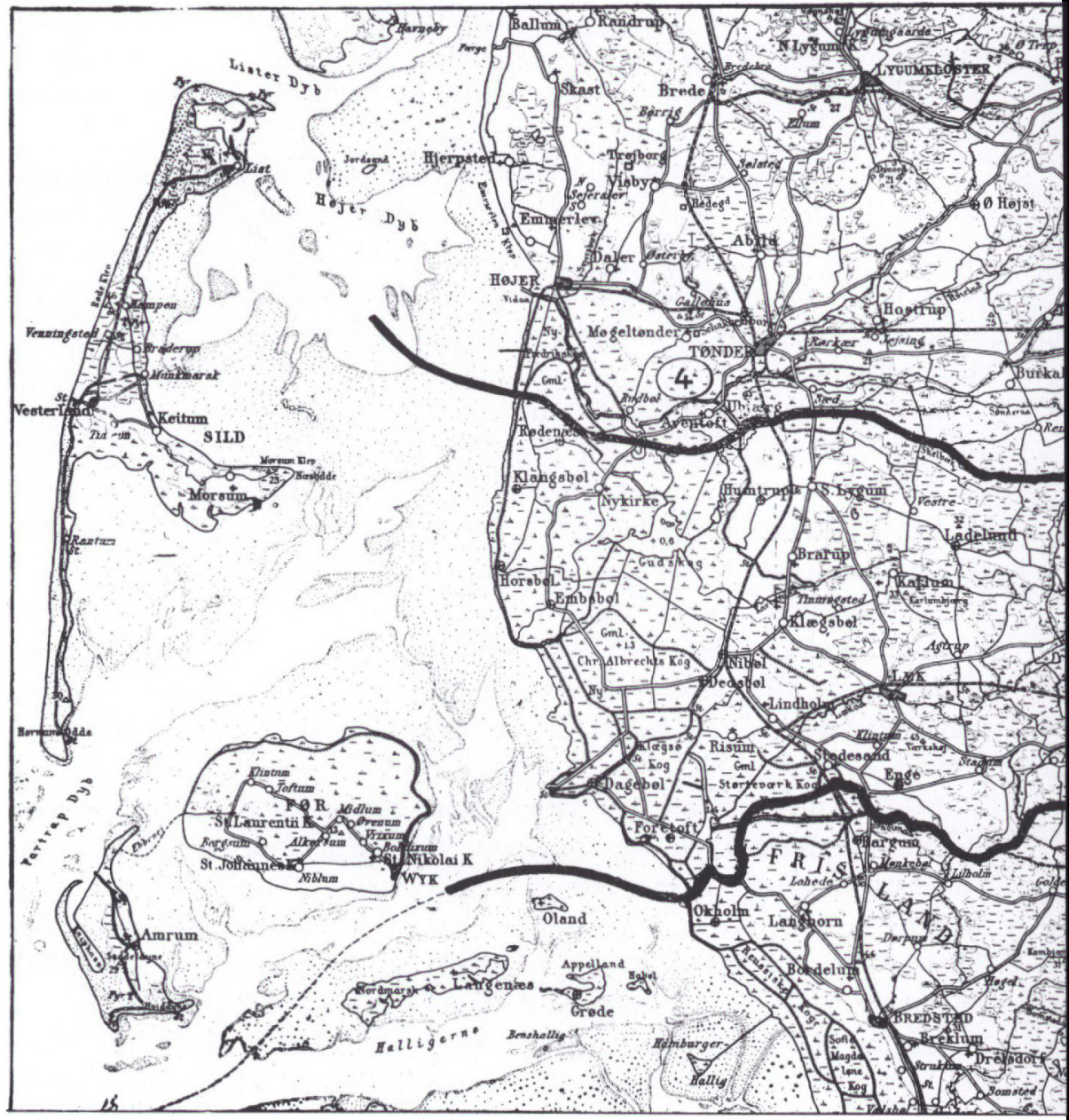

I sin pjece "For Afgorelsen" fra 1918 angav $\mathrm{H}$. V.Clausen på et kort de to granselinier, som han fandt forsvarlige. Det var den nordligste af disse to linier, som trekloveret Scavenius-Friis-H. P. Hanssen arbejdede for.

(hvori indenrigsminister Breitscheid deltog), som Nissen ikke måtte være med til. "At man har bundet sig til Skelbækken, foreligger der ingen beviser for, men uden sådant forstår man jo dårligt den hysteriskhed, hvormed man har holdt på denne ulykkelige linie.« Hanssen har afvist, at ministeriet Zahle har øvet nogen indflydelse på Vælgerforeningens grænsesætning, "men vejen dertil var $\mathrm{i}$ hvert fald kort, når han havde professor Friis til hånde«. - Såvidt Kloppenborgs mistro. ${ }^{21}$ 


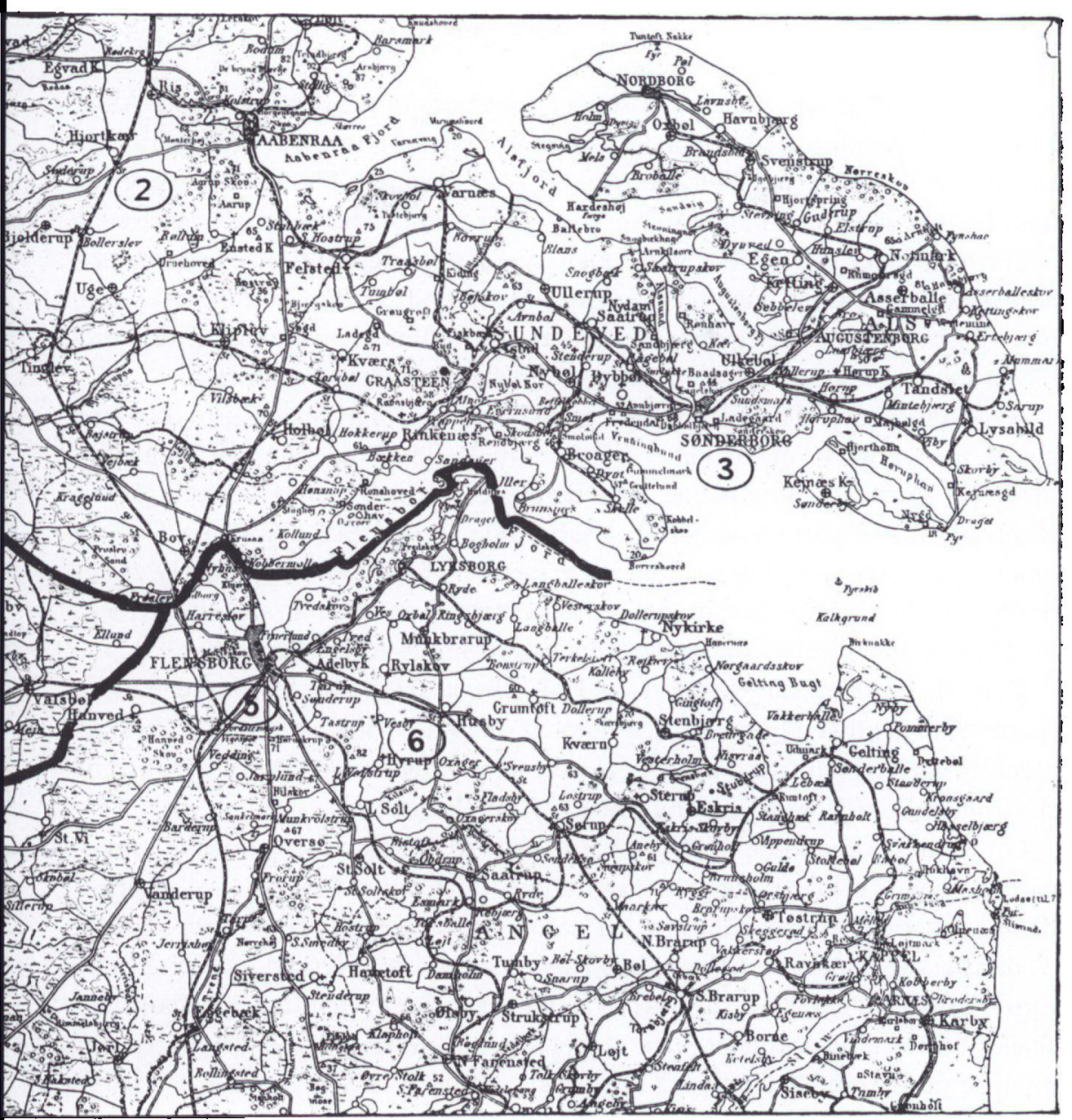

Faktisk havde Friis i Berlin diskuteret den fremtidige grænse såvel med Prøjsens indenrigsminister, dr. Breitscheid (der havde været villig til at tage med H.P.Hanssen for at tale i Aabenraa) ${ }^{22}$, som med udenrigsminister Solf. Over for Solf havde Friis fremhævet nordslesvigernes ønske om en national deling efter en fri folkeafstemning, og Solf spurgte så, hvilken grænse, der ville blive resultatet af en sådan afstemning. Da Friis udpegede Clausens linie (nord om Flensborg syd om Tønder), satte Solf spørgsmålstegn ved Tønder. Dette var den fremstilling, Friis gav i Tilskueren. Men i det originale manuskript formulerede Friis det noget anderledes: »Han spurgte mig, hvilken grænse jeg ønskede; jeg gav forklaring, hvorpå han tog et stort kort frem...«. - Nu spørger 
den tyske udenrigsminister næppe en dansk besøgende, hvilken grænse "han« ønsker, for at få en privat ønskeseddel.

Troels Fink har i de tyske akter fundet denne notits af Solf: "Professor Aage Friis har forhandlet med understatssekretær David og mig om muligheden af en grænselinie nord om Flensborg og syd om Tønder. Tilsagn er ikke givet ham fra vor side, men hans forslag er dog taget under velvillig overvejelse. ${ }^{23}$

Formuleringerne er afslørende. Den tyske udenrigsminister »forhandler« ikke grænsespørgsmål med en tilfældig privatmand. Endnu mindre overvejer han at give denne et tilsagn om en bestemt grænselinie. Friis er med andre ord blevet modtaget som repræsentant for den danske udenrigsminister.

Aage Friis har i Tilskueren givet et uskyldigt referat af den samtale, han havde med grev Rantzau inden afrejsen til Berlin. Han har her bare ikke medtaget Rantzaus usmykkede formulering. Af Friis' optegnelser fremgår, at Rantzau "meget gerne ville have, at jeg skulle tale med dr. David og Solf og understøtte hans synspunkter, som jeg jo kendte«, og at han gerne ville advisere det tyske udenrigsministerium om Friis' komme. Rantzau har altså introduceret Friis og har givetvis præsenteret ham som tilknyttet Scavenius.

Den 31. oktober var Rantzau og Friis blevet enige om det ønskelige i at fjerne den egentlige afgørelse fra Ententen, men det forudsatte ifølge Friis, at regeringen i Berlin hurtigst muligt "ganske utvetydigt anerkendte den Hanssenske grænse« nord om Flensborg, men syd om Tønder.

Grev Rantzau var den 4. november over for Friis gået ind på denne tankegang og havde erklæret sig enig $i$, at nu gjaldt det om at få den tyske regering til hurtigst muligt at proklamere en national grænse, der kunne tilfredsstille de danske og Danmark. Friis lovede Rantzau »absolut tavshed om dette, ikke fordi - som R. udtrykte sig - det var ham ganske ligegyldigt, om han blev skældt ud for landsforræder, men sagen ville blive ødelagt, hvis der sivede det mindste ud derom«.

Antagelig gik det forslag fra Friis, som Solf havde lovet velvillig overvejelse, da ud på, at den tyske regering ikke skulle nøjes med at acceptere selvbestemmelsesretten, men tillige begrænse den ved at proklamere sin tilslutning til en ny grænse nord om Flensborg og syd om Tønder (med afstemning nord for denne linie) for derved at gøre det vanskeligt for andre at ændre grænsens forløb.

Dermed falder endnu en brik på plads. Medens det er svært at se, hvorledes Solfs erklæring i den kendte form med tilsagnet om selvbestemmelsesret skulle kunne hjælpe H.P.Hanssen med at bremse danske Flensborg-ønsker, stiller det sig anderledes, hvis den tyske regering samtidig lagde sig fast på den af H.P.H. ønskede afstemnings- og grænselinie. Det må derfor have været H.P.Hanssens håb, at Friis med Danmarks udenrigsminister og Tysklands gesandt i ryggen kunne fremkalde denne ønskeløsning. 
Den danske gesandt i Berlin, grev C.Moltke, rapporterede hjem om et besøg, som han den 14. november havde aflagt hos udenrigsminister Solf lige efter, at denne havde konfereret med professor Friis: Solf erklærede sig i det store og hele enig med hensyn til den af nordslesvigerne foreslåede grænse og ville nu give H.P.Hanssen skriftlig bekræftelse på regeringens sindforståelse med den forestående proklamation om afstemningen inden for den planlagte grænse« og fremhævede "det ønskelige i, at man kunne holde sig til den nu vedtagne strengt nationale grænse ${ }^{24}{ }^{24}$ - Udtryk som "den planlagte grænse« og "den nu vedtagne strengt nationale grænse« tyder på, at Friis har udtrykt sig mere forpligtende end den tyske modpart. Desuden viser Solfs formuleringer, at man ikke blot har drøftet resultatet af en afstemning, men også den begrænsning af den "frie folkeafstemning«, der lå i, at Scavenius-FriisH.P.Hanssen arbejdede på at få fastlagt en sydgrænse for afstemningsområdet for at binde oppositionen og Ententen.

Den 15. november sendte grev Moltke efter anmodning fra Aage Friis et telegram til det danske udenrigsministerium, hvor det væsentlige afsnit lød således:

»Professor Friis til Udenrigsministeriet: »Har forhandlet med Hanssen, Haase, David, Solf og Breitscheid, hvilken sidste nu er i Indenrigsministeriet. Definitiv regeringserklaring undertegnet af Solf til nordslesvigerne om genforeningen er afgivet skriftligt til Hanssen og vil søndag af ham blive offentliggiort i Aabenraa samtidig med formulering af nordslesvigernes krav om genforening med angivelse af en ren nationalgrænse nord for Flensborg, syd om Tønder med afstemning under ét. Endelig afgørelse ved freden. Formel henvendelse fra nordslesvigerne til Danmark kommer i næste uge gennem Moltke. $\ll^{25}$

Der er i denne gengivelse i kildesamlingen $» D e t$ slesvigske spørgsmåls diplomatiske historie 1914-20«, der er udgivet af Udenrigsministeriet ved arkivar Fr. le Sage de Fontenay, en bemærkelsesværdig udeladelse. Ifølge Friis‘ originale manuskript, der befinder sig i Rigsarkivet, havde indledningen denne ordlyd: "Har forhandlet efter aftalte synspunkter med Hanssen, Haase..." osv. Det har ikke kunnet opklares, hvor de "aftalte synspunkter« er blevet af.

Har Fontenay ordlyden fra det modtagne telegram, skal opklaringen søges paa afsendersiden. I så fald skyldes udeladelsen sikkert Moltke, fordi det "aftalte« kunne kompromittere udenrigsminister Scavenius, der naturligvis ikke ville bryde sig om at skulle vedstå, at Friis havde fungeret som hans udsending.

På et møde i Tranebjerg på Samsø den 14. september 1919 afgav udenrigsministeren den utvetydige erklæring, at han sintet havde haft med professor Friis“ rejse at gøre«. Efter at være blevet presset måtte han dog erkende, at han whavde vidst om denne rejse og modtaget referat efter professorens 
hjemkomst . $^{26}$ - Når man nu ved, at Scavenius havde instrueret Friis inden rejsen, og at denne gennem gesandten havde sendt ministeren det triumferende rapport-telegram inden hjemkomsten, har dementiet jo ikke synderligt med sandheden at gøre.

I Tilskueren anførte Aage Friis, at det var en selvfølge, at han talte med udenrigsministeren inden rejsen, men at rejsen hverken direkte eller indirekte foregik i ministerielt ærinde. Papirerne i Rigsarkivet med hans referat af samtalen med ministeren modsiger imidlertid denne forklaring. Referatet lyder:

"I min samtale med Scavenius enedes vi om, at jeg med H.P.Hanssen skulle aftale følgende. $H$. burde sætte alle kræfter ind på hurtigst at få en klar og utvetydig offentliggørelse af, hvad den slesvigske befolkning og Vælgerforeningen onskede, både det positive (den nationale grænse) og det negative (at de ikke ville have Flensborg eller det sydligere med). Det bedste var jo ubetinget den Hanssen-Clausenske grænse definitivt fastslået med samlet afstemning, ja eller nej, nord for denne, hvorved al mulighed for en udstrækning af området sydpå var udelukket. Det er givet, at en sådan tilkendegivelse fra nordslesvigernes side ikke vil finde modstand fra Ententen."

Det var altså afgørende for Scavenius gennem Friis i forlængelse af formaningen i brevet af 3 . november til H.P. Hanssen ${ }^{27}$ at påvirke nordslesvigernes beslutning. Det bekræftes af hans heftige reaktion, da det viste sig, at Hanssen på Folkehjemsmødet havde måttet bøje sig for kravet om at åbne mulighed for en afstemning i Mellemslesvig. Da talte Scavenius om at gå af. ${ }^{28}$

$\mathrm{Nu}$ var det nemlig gennem nordslesvigerne, Scavenius ville binde Fredskonferencen. Derfor inkluderede udenrigsministerens instruks til Friis inden Berlinrejsen, at H.P.H. bør, "så snart Fredskonferencen adviseres, formelt rette henvendelse til denne om godkendelse af en sådan grænseforandring [dvs. en sådan grænseforandring som den, udenrigsministeren ønskede] og samtidig meddele den danske regering slesvigernes ønsker. Dermed ville sagen være i rette spor og således, at den danske regering kunne tage affære.»

Tilbage af forsøget på at få et dansk-tysk fait accompli i stand var altså kun ønsket om at få de nordslesvigske ledere bundet til en grænselinie, som Berlin accepterede, og som befolkningen - og Ententen - derefter måtte affinde sig med. Det ønske imødekom H.P. Hanssen så håndfast, at kritikerne følte sig bondefanget ${ }^{29}$ Men Scavenius var skuffet over, at det på Folkehjemsmødet ikke var lykkedes helt at afskære Ententens manøvremuligheder syd for Clausenlinien.

Foruden Rantzaus introduktion har Aage Friis sikkert haft nytte af at kunne medbringe varme hilsener fra Scavenius. Det falder i hvert fald i øjnene, at det første mål for Aage Friis er den danske gesandt, grev Moltke. Både den 
13. og den 14. november opsøger han efter H.P.Hanssen gesandten som den første. Man kan kun få det indtryk, at Aage Friis har benyttet gesandtskabet som sin operationsbasis, og det skulle være mærkeligt, om gesandten ikke har gjort, hvad han kunne, for at knytte de kontakter Aage Friis ønskede sig. Selvfølgelig er det utænkeligt, at en almindelig privatmand fra Danmark i disse kaotiske revolutionsdage skulle kunne lægge så meget beslag på travlt optagne tyske toppolitikere. Når den ene efter den anden af dem indtrængende lagde Aage Friis på sinde, at det var nødvendigt hurtigst muligt at hjælpe Tyskland med levnedsmidler, har de næppe heller opfattet ham som blot værende en privat besøgende.

Den 18. september 1919 følte Aage Friis sig nødsaget til at udsende en erklæring gennem Ritzau om sin rolle under Berlinbesøget. Han fastholdt, at han hverken under eller efter krigen havde søgt grænsespørgsmålet løst uden om Ententen, og at han i Berlin kun havde ført private samtaler med de tyske politikere. De verserende beskyldninger afviste han som usandheder og opspind. Men kritikerne havde mere ret, end Friis ville indrømme. Oktoberadressen kunne han ikke løbe fra, og i Berlin forhandlede han for Scavenius efter aftalte synspunkter.

\section{Scavenius i klemme}

Det kan ikke overraske, at de anstrengelser, Scavenius med følge udfoldede for at få sagen afgjort gennem direkte kontakt med Tyskland uden om de allierede, vanskeliggjorde forholdet til Ententen.

Erik Scavenius kom hurtigt i klemme på dette område. På det lukkede rigsdagsmøde den 23 . oktober 1918 beklagede han sig over de danske, der havde mistænkeliggiort ham hos Ententens gesandter i Danmark, så disse rejste problemet om de hemmelige underhandlinger med Tyskland over for deres regeringer, men han trøstede Rigsdagen med, at gesandterne desuagtet kun "som eneste instruktion « havde fảet ordre til at spørge ham, om der virkelig var forhandlinger $\mathrm{i}$ gang. "Udtalelser derudover foreligger ikke."

Da denne forsikring kom frem ved offentliggørelsen af Rigsdagens fortrolige slesvigske forhandlinger, opdagede Scavenius, at han var kommet $i$ et dilemma, for »der lå en notits [af 14. oktober 1918] fra den engelske chargé d'affaires, hvorefter denne havde ordre til at gøre opmærksom på farerne derved«. Det betroede Scavenius Munch den 14. januar 1920. Dagen efter fik Munch at vide, at Scavenius havde tænkt sig at skrive en lille redegørelse for, hvorledes det måtte antages at være gået til, og lægge den til akterne. ${ }^{30}$

Da Udenrigsministeriet i 1921 udgav Fontenays "Det slesvigske spørgs- 
måls diplomatiske historie 1914-20«, dukkede den søforklaring, som Scavenius havde udtænkt vedrørende den engelske verbalnote, op som aktstykke nr. 17, og vel at marke uden at det - hverken ved datering eller tekst blev antydet, at det drejede sig om en teoretisk rekonstruktion, der var forfattet fem fjerdingår efter hændelsen. Det begrænser unægtelig værdien af en sådan kildesamling.

Verbalnotens ordlyd $\mathrm{i}$ den ikke helt dækkende officielle oversættelse var: "Hans britiske Majestæt har modtaget efterretninger om, at der muligvis er indledet forhandlinger [is some possibility of negotations being initiated], hvorved Tyskland frivilligt skulle gå ind på at overdrage den dansktalende del af Sønderjylland som kompensation til Danmark. Jeg har af Hans Majestæts udenrigsminister fået ordre til at gøre den kongelige danske regering opmærksom på de alvorlige farer, såvel kommercielle som politiske, der ville kunne opstå ved at underhandle med Tyskland på dette tidspunkt [which would be run by siding with Germany at such a moment]«.

Det var med andre ord oplagt, at Scavenius den 23. oktober 1918 havde givet Rigsdagen forkert besked. Der var slet ikke tale om et spørgsmål, men om en klart formuleret engelsk advarsel imod at stille sig ved Tysklands side, og det ramte ikke blot de anstrengelser, Scavenius notorisk gjorde sig for at præsentere de allierede og Fredskonferencen for et dansk-tysk fait accompli, men også Oktoberadressen og dens tilbud til Tyskland om at hjælpe med at bygge bro til de tidligere fjender. Ingen dementier af igangværende forhandlinger kunne fjerne eksistensen og berettigelsen af denne advarsel.

Alligevel påstod Scavenius nu i aktstykke nr. 17 med tilbagevirkende kraft, at instruksen ikke kom til udførelse, fordi dens grundlag manglede, eftersom han havde dementeret rygterne om dansk-tyske forhandlinger, og at verbalnoten derfor i forhold til den danske regering var at betragte som ikke-eksisterende! »Jeg modtog dog verbalnoten, da det forekom mig at være af interesse at være $i$ besiddelse af dette vidnesbyrd om visse herfra landet udgånde bestræbelser!

Hvor let man kunne blive vildledt af udenrigsministerens manøvre, viser Historielærernes læsehefte for gymnasiet »Kilder til Genforeningens historie«, samlet af E. Holbech i 1950. Han skriver om lord Kilmarnocks verbalnote: "Scavenius nægter imidlertid at tage imod den, da der intetsomhelst grundlag er for dens fremkomst.«

Iøvrigt kaldte udenrigsminister Erik Scavenius - stadig ifølge aktstykke nr.17 - efter samtalen med lord Kilmarnock den franske og den italienske gesandt og den amerikanske chargé d'affaires til sig enkeltvis og afgav den samme erklæring til dem, det vil sige dels et dementi af rygterne om dansktyske forhandlinger, og dels en udtalelse om, at lige så selvfølgeligt det var, at 
den tyske regering ønskede sådanne direkte forhandlinger, lige så klart var det, at den danske regering ikke kunne indlade sig derpå.

Vi kender lidt mere til disse samtaler fra andre kilder end den scavenianske rekonstruktion. Troels Fink har således gransket Ententegesandternes indberetninger. ${ }^{31}$ Den amerikanske chargé d'affaires, U. Grant-Smith, havde allerede den 12. oktober forelagt sin regering rygterne i den vitterlig korrekte form, at den danske regering havde henstillet til den tyske at få arrangeret en frivillig afståelse, så Danmark ikke udsatte sig for senere tysk hævn.

Grant-Smith lod sin viden gå videre til den franske gesandt, A. Conty, og den engelske lord Kilmarnock, som begge nåede at rapportere hjem den 12. oktober. De meddelte, at Grant-Smith havde talt med udenrigsminister Scavenius og advaret imod for nær tilknytning til Tyskland, for det ville kunne få konsekvenser for de allieredes holdning. Scavenius havde svaret, at det var første gang, han havde hørt sådanne rygter, men han havde ladet forstå, at Danmarks situation ville være vanskelig, hvis Slesvig blev givet tilbage til Danmark af de allierede efter krav fra Danmarks side, hvoraf de sluttede, at den nuværende danske regering hellere vilde have Slesvig tilbage af tyskerne end af de allierede.

Conty oplyste desuden, at Scavenius indirekte havde sagt til Grant-Smith, at han ikke ville tillade en sådan grænseregulering, og hvis sonderinger var indledt, ville de ikke blive fulgt op. - Sagt på et tidspunkt, hvor Scavenius stærkt håbede, at grev Rantzau ville få hans plan til at lykkes, var slig tale referatets rigtighed forudsat - at opfatte som vildledning.

Der findes også et dansk referat af den samtale, Scavenius havde haft med Grant-Smith. Scavenius havde nemlig omtalt samtalen over for Zahle og Friis under sammenkomsten den 13. oktober. Friis fortæller, at den amerikanske diplomat havde spurgt Scavenius, om det var sandt, at man havde fået en overenskomst med Tyskland om Nordslesvig på lidet tilfredsstillende vilkår for Danmark. - I denne udgave, der er gået gennem Scavenius-Friis, er amerikanerens formulering ikke til at kende igen.

Efter det traditionelle dementi fortsatte Scavenius ifølge Friis med følgende forklaring til amerikaneren: "Lige så lidt som man kunne finde sig $\mathrm{i}$ at yde Tyskland militær eller økonomisk gengældelse, lige så lidt kunne man af hensyn til det slesvigske spørgsmål træde $i$ et forhold til Tysklands fjender, der kunne kompromittere vort forhold til Tyskland.... Danmark havde jo ikke som de krigsførende magter noget krav at rette til Tyskland i det nordslesvigske spørgsmål. Noget ganske andet var, om man [altså Danmark] kunne få Tyskland til med det gode som en konsekvens af den nye tilstand at indrømme de danske nordslesvigere, at de havde et berettiget krav på en grænseflytning. På denne måde søgte Scavenius indirekte at vise amerikaneren, at man ikke 
ønskede en Entente-intervention i sagen, hvis det ikke blev absolut nødvendigt. ${ }^{32}$

Tilsvarende havde Scavenius forklaret den konservative politiker Alex. Foss, at »det var lige så farligt at få det [Nordslesvig] ved Ententens bestræbelser, som det under krigen ville have været at få det ved en overenskomst med Tyskland«. - Zahle og Friis erklærede sig enige i dette standpunkt.

Herefter kommer den forklaring, som Scavenius gav i aktstykke 17 for amerikanerens vedkommende til at stå i et ejendommeligt lys. Udenrigsministeren kan vanskeligt have tilkaldt Grant-Smith den 14. oktober for at dementere muligheden af forhandlinger, der skulle inspirere Tyskland til frivilligt at afstå Nordslesvig, når han selv den 12. oktober havde forklaret samme GrantSmith, at det præcis var, hvad hans samtalepolitik gik ud på.

Man må også sætte spørgsmålstegn ved dybden af udenrigsministerens forargelse, når han på det lukkede rigsdagsmøde den 23 . oktober hudflettede "rygte-smedene her i landet « og »de allieredes sufflører her i byen«, fordi de hos de allierede havde skabt mistænksomhed vedrørende »dette, at vi allerede for nærværende skulde befinde os i underhandlinger med Tyskland«; »jeg har netop peget på, at denne sag ikke kunne komme til afgørelse før Fredskonferencen, altså at en forhåndsaftale med Tyskland var udelukket.«

Man skal lægge mærke til udtrykkene »underhandlinger « og »forhåndsaftale«. Med denne drejning afviste Scavenius landstingsmand Foss, der havde advaret imod en »forhåndsforståelse« med Tyskland forud for fredsforhandlingerne.

Da Scavenius en måned senere, den 25. november 1918, i Rigsdagens politiske forhandlingsudvalg direkte blev spurgt, om ministeriet havde fået henvendelse fra den tyske udenrigsminister angående Sønderjylland, eller om der var ført forhandlinger med ministeriet direkte angående et sådant skridt fra tysk side, valgte han meget kryptiske vendinger til sit svar: »Jeg må mene, at der ikke har været ført sådanne forhandlinger. Selvfølgelig har der været ført samtaler om spørgsmålet. Men det har hele tiden været hævdet, at der ikke på det hidtidige stadium kunne føres forhandlinger med den tyske regering. Måske er det fra tysk side blevet sagt, at man hellere ville forhandle med Danmark end med Tysklands fjender. Men vi har afvist forhandling.« - I.C. Christensen ønskede forhandlings-perspektivet præciseret: »Der har altså ikke været forhandlet med den tyske gesandt, men man har henvist til de danske i Sønderjylland? « - Scavenius: »Ja! Der er overhovedet ingen henvendelse sket. ${ }^{33}$

Indadtil var de indviede knap så bange for at bruge ordet forhandlinger. Som Aage Friis beroligende skrev til H.P.Hanssen den 15. oktober 1918: "Samtidig vil der selvfølgelig blive passet på ikke ved forhandlingerne med Tyskland at kompromittere os over for Ententen.« Og Friis var sig meget 
bevidst, at han havde været midtpunkt $\mathrm{i}$ forhandlinger, da han opholdt sig $\mathrm{i}$ Berlin. Som nævnt indledte han sit rapport-telegram til Scavenius om resultatet med ordene »har forhandlet « med Hanssen, Haase, David, Solf og Breitscheid. Men i det originale manuskript kan man se, at Friis først skrev »talt med « $\mathrm{i}$ stedet for »forhandlet med«. Ordet "talt" er derefter blevet overstreget og erstattet med den mere dakkende betegnelse. Det var kun over for offentligheden, at forhandlingerne blev reduceret til private samtaler.

Også hos udenrigsministeren var der forskel på dementier og realiteter. Selv om han bortset fra grænselinien havde opgivet sin plan om at stille Fredskonferencen over for et dansk-tysk fait accompli, var det dog en kendsgerning, at han underhånden havde henvendt sig til Berlin derom gennem den tyske gesandt, og at han selv havde bidraget til at gøre rygterne troværdige ved at afsløre sin egen holdning til sagen over for den amerikanske chargé d'affaires.

Spørgsmålet, hvornår og hvorfor Scavenius er kommet på andre tanker, har ikke kunnet besvares. Viggo Sjøqvist mener, at lord Kilmarnocks verbalnote den 14. oktober må have gjort et stærkt indtryk på Scavenius. ${ }^{34}$ Formodentlig har Sjøqvist ret, selv om Scavenius den 14. januar 1920 under sine bortforklaringer lod Munch forstå, at han måske ikke engang havde læst den. Grev Rantzau har også fået bibragt den opfattelse, at det var Ententens protester, der gjorde, at den danske regering havde måttet trække sig ud af de winoffizielle Besprechungen « med Tyskland. ${ }^{35}$

Så sent som den 17. oktober 1918 håbede Scavenius, at man kunne få sagen lagt fast for Fredskonferencen, og endnu senere stolede han på, at det i hvert fald kunne lade sig gøre med hensyn til selve grænseforløbet.

$\mathrm{Da}$ H.V.Clausen som den danske regerings udsendte sagkyndige i $1919 \mathrm{kom}$ til Paris for at bistå gesandten med at bjerge en for Danmark tilfredsstillende løsning gennem Fredskonferencen, fik han de negative følger af kontaktarbejdet med Tyskland at mærke. I H.V.Clausens arkiv i Rigsarkivet kan man finde et brev til Mackeprang af 22. maj 1919, hvori han ikke lægger skjul på, at oktoberadressen har skadet hans arbejde i Paris:

"Hvor kan en svaghed $i$ en enkelt time have skæbnesvangre følger - jeg burde aldrig være gået med til den ulykkelige adresse. Den har været præsenteret hernede i dens første utilgiveligt dumme form, af Conty, og utvivlsomt også af Ionas Collin og Bent Holstein, og dermed er min autoritet som sagkyndig bleven svækket og omtvistet. Ak, den søndag formiddag og den usalige Friis! «

I et andet brev til Mackeprang udbryder H.V.Clausen: "Den forbandede adresse!

Hos Mackeprang er disse udbrud sikkert blevet modtaget med megen forstå- 
else. Han fortrød, at han havde undladt at præsentere sit eget udkast til en adresse som et alternativ til det udkast, Friis var kommet med. Det fremgår af en påskrift, dateret 24. oktober 1938, på hans eget udkast. ${ }^{36}$

Fru Mackeprang var ikke så længe om at forkaste adressen. Da hendes mand kom hjem fra Friis, udbrød hun straks: "Hvor kunne du gå med til den!« Det har H.V.Clausen noteret i en randnote på en afskrift, der ligger i Rigsarkivet. Og han tilføjede: "Da jeg kom hjem til min kone, sagde hun det selvsamme.«

\section{Spørgsmålstegn ved grænsedragningen}

Udenrigsminister Erik Scavenius, professor Aage Friis og H.P. Hanssen mente, at de $\mathrm{i}$ deres bestræbelser havde holdt sig indenfor rigsdagsresolutionen af 23. oktober 1918. Men denne talte om en grænse trukket efter nationalitetsprincippet: folkenes selvbestemmelsesret. Det strider imod denne grundtanke på forhånd at cementere en grænse syd om Tønder, der både i 1864 og 1920 fremviste et stort tysk flertal, og på den anden side at ville udelukke Flensborg fra at stemme, skønt denne by i 1864 havde dansk flertal og i 1920 viste sig at have større dansk stemmeandel end Tønder.

Manøvrerne for at opnå det attråede grænseforløb tålte ikke dagens lys. Med dementier og skruede bortforklaringer er der skjult et spil, som undertiden udartede til dobbeltspil, og som i alle tilfælde fremkaldte en mistro hos oppositionen, der anede det værste. Det er naturligvis gjort ud fra den overbevisning, at man derved bedst gavnede danske interesser på langt sigt. Alligevel har jeg her måttet lagge nogle flere skygger ind i det rehabiliterende billede, jeg har givet af Erik Scavenius i Sønderjysk Månedsskrift 1973, side 405-417.

Det skjulte spil, som oppositionen dels fornemmede, dels fik afdækket og dels fik overdrevne forestillinger om på grund af voksende skepsis over for de ministerielle dementier, bidrog afgørende til at skærpe de modsætningsforhold og den bitterhed, der skæmmede grænsestriden.

Selvsagt var det af betydning at søge den nye grænseordning gennemført $\mathrm{i}$ forståelse med Tyskland, og den tyske regeringserklæring gjorde det lettere både for H.P.Hanssen og den danske regering at arbejde videre med sagen. Men dels havde de anvendte midler uheldig karakter, dels lå der ikke den forventede garanti i tyske forsikringer, der under øjeblikkets pres blev afgivet af en midlertidig revolutionsregering.

Man kan undre sig over, at H.P.Hanssen så stærkt insisterede på at få den tyske regeringserklæring med netop Solfs underskrift, så tilbud om underskrift af Ebert og Haase blev afvist. Wilhelm Solf var kun udenrigsminister fra 4. 
oktober til 13. december 1918, og efter revolutionen endda uden virkelig autoritet. H.P.Hanssen har selv forklaret, at han foretrak Solf blandt andet, fordi denne wi tilfælde af et nyt uventet regeringssskifte ville binde en borgerlig regering stærkere ${ }^{37}$. Men dermed har han samtidig peget på, hvor ringe tillid han $\mathrm{i}$ virkeligheden havde til værdien af en sådan regeringserklæring.

Det viste sig hurtigt, at erklæringen fra Solf, der jo ikke gik ind for en bestemt grænse, men nøjedes med en generel henvisning til præsident Wilsons fredsprogram og folkenes selvbestemmelsesret, allerede $\mathrm{i}$ afstemningstiden gav vide rammer for en tysk-nationalistisk agitation. Heller ikke sidenhen gav Solfs erklæring den sikkerhed for grænsen, som man fra dansk side havde håbet på.

Et blad som »Politiken« måtte allerede den 2. februar 1924 erkende, at alle tyske partier - også Socialdemokratiet - havde udtalt sig imod den nye grænse. Bladet sammenfattede den 8. februar 1924 situtionen således: "Vi stolede i sin tid på, at vor nationale grænsepolitik ville vinde forståelse og anerkendelse overalt, og at den ærlige og loyale holdning ville sikre os et godt forhold til Tyskland. Vi må nu erkende og tage konsekvensen af den erkendelse, at i det nuværende Tyskland er der intet parti, der oprigtigt anerkender grænsen."

At den tilrettelagte forståelsespolitik, baseret på aftalte synspunkter og en tysk regeringserklæring, ikke gav grænsen sikkerhedssegl, fremgår også af en tale, som den fremtrædende socialdemokrat, senere undervisningsminister Hartvig Frisch, holdt ved Studentersamfundets rusmodtagelse den 3. september 1929. Han kaldte det et nationalt dogme, at Danmarks sydgrænse var fremgået af en afstemning på grundlag af sønderjydernes nationale selvbestemmelsesret. Det hindrer os i at forstå ikke blot de uforstandige, men også de forstandige tyskere. "Sandheden er den, at grænsen er draget af H.P.Hanssen og H.V.Clausen. " $^{38}$

Endog i H.P.Hanssens gamle blad, "Hejmdal«, blev der rokket ved grænsen, dog først nogle måneder efter hans død. Den 30. januar 1937 bragte bladet et indlæg, som opfordrede de tyske i Nordslesvig til at præcisere deres konkrete grænsekrav med henblik på en fredelig forhandling om spørgsmålets løsning. Det bemærkelsesværdige var, at »Hejmdal« bragte dette indlæg anonymt og placeret som ledende artikel. - Et sønderjysk vådeskud!

Ja, selveste Erik Scavenius har været med til at sætte spørgsmålstegn ved grænsedragningens retfærdighed og holdbarhed. Da han efter sin udnævnelse til udenrigsminister den 10. juli 1940 opsøgte den tyske gesandt, nævnte han, at han så en stor vanskelighed $i$ det nordslesvigske spørgsmål. Han havde tidligere søgt at få den danske regering til at komme til direkte forståelse med Tyskland, »men han havde desværre talt for døve øren«. At tage sagen op på nuværende tidspunkt som et særskilt spørgsmål, kunne næppe nogen dansk 


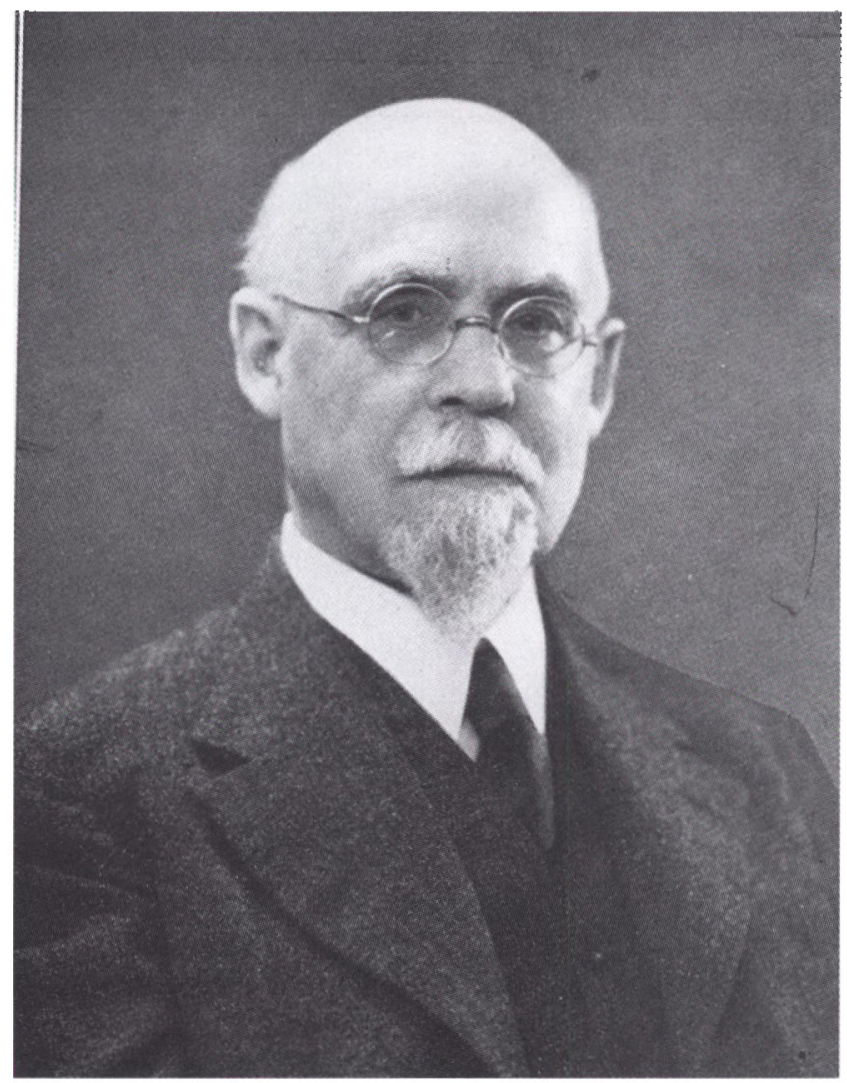

Professor Aage Friis (1870-1949), der var radikal, var fra sin ungdom engageret $i$ det sonderjyske sporgsmål og gjorde meget for at skabe forståelse for det også $i$ den del af befolkningen. som havde stillet sig mere kølig. Friis arbejdede pd at hjalpe de danske sonderjyder til rimeligere vilkair under det tyske styre. Men $i 1902$ erklarede han det for en ulykke, om det danske Nordslesvig blev genforenet med Danmark efter en europaisk krig, hvori Tyskland bukkede under, thi kun $i$ venskab med Tyskland kunne det nordslesvigske sporgsmål loses. Da ulykken narmede sig i 1918, var det logisk, at Friis sogte tysk samarbejde om den nye granse, og samtidig nodvendigt, at han skjulte sine bestrabelser for de allierede og for den danske opposition. Derfor fremstillede han sine forhandlinger med regeringen $i$ Berlin i november 1918 som helt private. Men private var de ikke. Den 15.11 .1918 afsendte gesandten $i$ Berlin efter anmodning fra Friis et telegram, der begyndte således: "Professor Friis til Udenrigsministeriet: "Har forhandlet med Hanssen. Haase, David, Solf og Breitscheid ..."." Men der er udeladt nogle afslorende ord. Det efterladte manuskript, der her for forste gang er fremdraget, viser, at Friis havde denne indledning: "Har forhandlet efter aftalte synspunkter med Hanssen, Haase, David, Solf og Breitscheid ..... Det er hidtil altid blevet benagtet, men telegrammet plus de fjernede ord beviser, at de forhandlinger, professor Friis forte med regeringen i Berlin, var aftalt med den danske udenrigsminister. 
regering holde til. Dersom Tyskland ikke kunne afstå fra på ny at stille problemet til diskussion, ville det nok være bedst at drøfte det $\mathrm{i}$ forbindelse med nyordningen af Europa. ${ }^{38}$

Skønt Erik Scavenius fik grænsen trukket, som han ønskede det, var han selv med til at underminere den sikkerhed, der skulle være knyttet til den.

Datoliste (1918)

23. 9. Forsvarsminister P. Munch foreslår regeringen, at man enes med Tyskland om den nye grænse.

9.10. Udenrigsminister Erik Scavenius opfordrer gennem gesandten, grev Rantzau, den tyske regering til at komme med et udspil.

12.10. U.S.A.s gesandtskab advarer Scavenius.

13.10. Oktoberadressen bliver til og forener de to fjender, Erik Scavenius og professor Aage Friis.

14.10. England advarer Scavenius.

17.10. Made mellem ministeriet og partiernes formænd.

17.10. Den tyske gesandt, grev Rantzau soger at vinde sin regering for Scavenius' plan.

18.10. Th. Stauning appellerer til sine tyske partifæller om stotte til Scavenius' plan.

20.10. Mystik om dansk henvendelse til den tyske regering.

23.10. H.P. Hanssen rejser $i$ den tyske rigsdag kravet om gennemferelse af Pragfredens $\$ 5$.

23.10. På et fortroligt fællesmøde slutter Folketing og Landsting sig til ønsket om en grænse i overensstemmelse med nationalitetsprincippet: Folkenes selvbestemmelsesret.

8.11. Aage Friis beslutter at tage til Berlin og drøfter rejsens formål med udenrigsminister Scavenius og den tyske gesandt, grev Rantzau.

9.11. Revolution i Tyskland.

11.11. K1. 11 Våbenstilstand.

14.11. Aage Friis forhandler med den nye tyske regering og får en skriftlig erklæring om, at også det nordslesvigske spørgsmål skal løses på grundlag af selvbestemmelsesretten.

16.-17.11. Tilsynsrådet $\mathrm{i}$ den nordslesvigske valgerforening tager stilling til grænsespørgsmålet på Folkehjem i Aabenraa.

\section{FORKORTELSE AF LITTERATURKILDER}

Fink/ Troels Fink: »Da Sønderjylland blev delt 1918-1920«, bd. I (1978)

Fontenay/Fr. le Sage de Fontenay: "Det slesvigske spørgsmåls diplomatiske historie 1914-20" Aktafdelingen (1921)

Grv./ Tidsskriftet "Grænsevagten«, bd. II (1919-20)

Munch/ P. Munch: »Erindringer 1918-1924« (1963)

Sdj.Årb./ Harald Jørgensen: „Oktoberadressen« (i Senderjyske Årbøger 1957, p 99-236)

Tyskerkursen/ Bjørn Svensson: »Tyskerkursen « (1983) 
NOTER

1. Fink, p. 4.

2. Fink, p. 26.

3. Fink, p. 32.

4. Fink, p. 103.

5. Tyskerkursen, p. 129.

6. P. Munch: "Erindringer 1914-1918« (1961), p. 339.

7. Fink, p. 17.

8. Friis' privatarkiv i Rigsarkivet.

9. Munch, p. 16.

10. Fink, p. 53.

11. Tyskerkursen, p. $138 \mathrm{ff}$.

12. Tyskerkursen, p. $142 \mathrm{ff}$.

13. Harald Jørgensen: „Genforeningens statspolitiske baggrund« (1970), p.43.

14. Sdj. Årb., p. 114.

15. Tyskerkursen, p. $153 \mathrm{ff}$.

16. Fontenay nr. 164, p. 332f., jfr. Jørgen Hatting: "Fra Piper til Christmas Møller 1915-1929« (1966), p. 122.

17. Sdj. Årb., p. 222 (Brev fra Aage Friis 3.11.1918).

18. Sdj. Årb., p.228 ff.

19. Fink, p. 58.

20. H.P. Hanssen: »Fra krigstiden«, bd. II (1924), p.402.

21. Dagbladet "Danskeren« 4.6.1920, sml. »Slesvig delt« (1922) p.16 f.

22. Flensborg Avis 26.8.1919, cit. Grv., p. 213.

23. Fink, p. 59.

24. Fontenay, nr. 53.

25. Fontenay, nr. 52.

26. Samsø Avis 19.9.1919, cit. Grv., p. 216.

27. Som note 17.

28. Munch, p. 41.

29. Grv., p. 494-504.

30. Munch, p. 171.

31. Fink, p. 2o f.og 43, jfr. Tage Kaarsted: »Storbritannien og Danmark 1914-1920« (1975), p. 146.

32. Tyskerkursen, p. 149.

33. Fontenay, nr. 60.

34. Viggo Sjøqvist: "Erik Scavenius«, bd. I (1973), p. 277.

35. Schleswigsche Grenzpost 12.3.1919, cit. Grv., p. 208.

36. Sdj. Årb., p. 108.

37. H.P.Hanssen: »Grænsespørgsmålet« (1920), p.68 f.

38. Grænsevagten, bd. IX (1929), p. 309.

39. Parl.komm., XIII, bd. 1, p. 256. 